\title{
Physical activity level and associated factors: an epidemiological study with elderly
}

\author{
Nível de atividade física e fatores associados: \\ um estudo epidemiológico com idosos
}

\begin{abstract}
Nivel de actividad física y factores asociados: un estudio epidemiológico con ancianos
\end{abstract}

\author{
Daniel Vicentini de Oliveira ${ }^{[a]}$, Celita Salmaso Trelha $\circledast^{[b]}$, \\ Lilian Leonel de Lima ${ }^{[a]}$, Mateus Dias Antunes ${ }^{[c]}$, José Roberto Andrade do Nascimento Júnior@[d], \\ Sônia Maria Marques Gomes Bertolini@[e]*
}

\footnotetext{
[a] Centro Universitário Metropolitano de Maringá (Unifamma), Maringá, PR, Brazil

[b] Universidade Estadual de Londrina (UEL), Londrina, PR, Brazil

${ }^{[c]}$ Universidade de São Paulo (USP), São Paulo, SP, Brazil

[d] Universidade Federal do Vale do São Francisco (Univasf), Petrolina, PE, Brazil

${ }^{[\mathrm{e}]}$ Centro Universitário de Maringá (Unicesumar), Maringá, PR, Brazil
}

\begin{abstract}
Introduction: This study is relevant insofar since it provides information on the elements that interfere in the level of physical activity of the elderly that attend the Fitness zone. Objective: Identifying the level of physical activity and its associated factors related to the elderly who usually go to third age fitness centers in Maringá/PR. Method: A cross-sectional study was carried out with 970 elderly users of the Fitness zone of the municipality of Maringá, state of Paraná, Brazil. A sociodemographic questionnaire and the International Physical Activity Questionnaire (IPAQ) was used. The data were analyzed by the Pearson's Chi-squared, the Binary Logistic
\end{abstract}

\footnotetext{
* DVO: PhD, e-mail: d.vicentini@hotmail.com CST: PhD, e-mail: celita@uel.br LLL: BS, e-mail: lilianlima19@hotmail.com MDA: Doctoral student, e-mail: mateus_antunes03@hotmail.com JRANJ: PhD, e-mail: jroberto.jrs01@gmail.com SMMGB: PhD, e-mail: smmgbertolini@yahoo.com.br
} 
Regression and the Hosmer-Lemeshow test $(p<0,05)$. Results: The data indicates that being married $(p=0,047)$ and having completed higher education $(p=0,001)$ is significantly associated with higher physical activity level. The lower use of medication ( $p=0,008)$, the excellent health perception $(p=0,037)$, and no history of near-falls $(p=0,038)$ were associated with the physical activity practice. The subjects who had no history of near-falls in the last six months and who did not have osteoporosis were 1.671 [95\% CI $=1.009-2.613]$ and 1.891 [95\% $\mathrm{CI}=1.008-2.915]$ times more likely to be active/very active when compared to the elderly who had near-falls in the last semester and who had osteoporosis. Conclusion: It was concluded that sociodemographic variables and health conditions are associated to the physical activity level in the elderly. Further, elderly who reported the absence of a history of near falls and osteoporosis have more chance to be physically active.

Keywords: Aging. Motor Activity. Exercise. Public Health.

\section{Resumo}

Introdução: Este estudo é relevante na medida em que fornece informações sobre os elementos que interferem no nível de atividade física dos idosos que frequentam as Academias da terceira idade (ATI). Objetivo: Identificar o nível de atividade física e seus fatores associados relacionados aos idosos frequentadores das ATI em Maringá/PR. Método: Estudo transversal, realizado com 970 idosos usuários das ATI da terceira idade do ATI, do município de Maringá, estado do Paraná, Brasil. Utilizou-se um questionário sociodemográfico e o International Physical Activity Questionnaire (IPAQ). Os dados foram analisados pelo teste Qui-quadrado de Pearson, a Regressão Logística Binária e o teste de Hosmer-Lemeshow $(p<0,05)$. Resultados: Os dados indicam que ser casado $(p=0,047)$ e ter ensino superior completo $(p=0,001)$ está significativamente associado ao maior nível de atividade física. $O$ menor uso de medicamentos $(p=0,008)$, a excelente percepção de saúde $(p=0,037)$ e ausência de história de quase quedas $(p=0,038)$ foram associados à prática de atividade física. Os sujeitos que não tinham história de quase quedas nos últimos seis meses e que não tinham osteoporose tiveram 1,671 [IC95\% = 1,009-2,613] e 1.891 [IC 95\% = 1,008$2,915]$ vezes mais probabilidades de ser ativo / muito ativo quando comparado com os idosos que tiveram quase quedas no último semestre e que tiveram osteoporose. Conclusão: Concluiu-se que as variáveis sociodemográficas e as condições de saúde estão associadas ao nível de atividade física do idoso. Além disso, idosos que relataram a ausência de história de quase quedas e osteoporose têm mais chance de serem fisicamente ativos.

Palavras-chave: Envelhecimento. Atividade Motora. Exercício. Saúde Pública.

\section{Resumen}

Introducción: Este estudio es relevante pues brinda información sobre la interferencia en el nivel de actividad física de ancianos frecuentadores de gimnasios de tercera edad (GTE) en Maringá (Brasil). Objetivo: Identificar el nivel de actividad física y sus factores asociados de los ancianos que usualmente acuden a GTE en Maringá. Método: Estudio transversal con 970 ancianos de GTE en Centros de Aptitud Tercera Edad de Maringá. Se utilizaron un cuestionario sociodemográfico y el Cuestionario Internacional de Actividad Física (IPAQ). Los datos se analizaron mediante la Chicuadrado de Pearson, la Regresión logística binaria y la prueba de Hosmer-Lemeshow $(p<0,05)$. Resultados: Los datos estar casado $(p=0,047)$ y haber completado la educación superior $(p=0,001)$ indican asociación significativa con el nivel de actividad física más alto. La reducción de medicaciones $(p=0,008)$, la excelente percepción de salud $(p=0,037)$ y la ausencia de caídas antecedentes $(p=0,038)$ se asociaron con la práctica de actividad física. Los sujetos sin antecedentes de casi caídas en los últimos seis meses y sin osteoporosis eran 1.671 [IC 95\% =1.009-2.613] y 1.891 [IC 95\% = 1.008-2.915] veces más propensos a ser activos/muy activos cuando se comparan a los que tuvieron casi caídas en el último semestre y con osteoporosis. Conclusión: Se concluyó que las variables sociodemográficas y las condiciones de salud están asociadas al nivel de actividad física del anciano. Además, los que relataron la ausencia de casi caídas y de osteoporosis tuvieron más posibilidades de ser físicamente activos.

Palabras clave: Envejecimiento. Actividad Motora. Ejercicio. Salud Pública. 


\section{Introduction}

Population aging is a major challenge for the health system in Brazil, thus, one of the strategies is ensuring active and healthy aging through integrated actions at all levels of care, including strategies that shall promote health $[1,2]$.

Regular physical activity contributes to reduce the complications of non-communicable chronic diseases that mainly affect the elderly, in addition to reducing costs, increasing social benefits and positively interfering in their quality of life [3]. Furthermore, physical activity practice has been increasingly recommended due to its recognized physical, psychological and social benefits, especially among the elderly, since it promotes independence, health and quality of life; moreover, it shall reduce the use of the health service and medicines, the risk of developing chronic illnesses or diseases, death and institutionalization [4].

Surveillance and monitoring studies in physical activity have pointed to high prevalence of physical inactivity among the elderly in different regions of the world, such as Australia (50.8\%), New Zealand (51.4\%), Colombia (62.4\%), Switzerland (67.5\%) and Sweden representing the highest rate $72.2 \%$. This prevalence in Brazil corresponds to 59.3\% [5]; in the same way, it has been characterized by presenting worrying data regarding the prevalence of physical inactivity in the elderly population [6]

With the purpose of incorporating actions that might promote the quality of life in both the routine of the health services and the daily life of individuals, considering the reduction of morbimortality, complications of chronic noncommunicable diseases, and the number of hypertensive and diabetic older people. In addition to the health benefits through physical activity, the Fitness zone (FZ) was implanted by the City Hall of Maringá city, state of Paraná (PR) through a partnership with the Secretary of State for Health and Social Care, the Secretary of State for Sport, and private companies that support the equipment purchase.

Maringá is a municipality located in the north of Paraná. In the last Demographic Census of 2010, the city of Maringá had 357,077 inhabitants and of these, $12.2 \%$ are elderly. The municipality has a population density of 733.14 inhabitants per $\mathrm{km}^{2}$. Considering households with monthly incomes of up to half a minimum wage per person, it had $26.1 \%$ of the population in these conditions, which placed it in position 377 of 399 among the state cities and in position 5,233 of 5,570 among the cities of Brazil. In addition, it presents $83 \%$ of households with adequate sanitary sewage, $97.3 \%$ of urban dwellings in public roads with afforestation and $90.6 \%$ of urban dwellings in public roads with adequate urbanization (presence of manhole, sidewalk, paving and curb) [7].

These FZs are made up of metallic equipment that can be used for performing stretching and muscular endurance exercises, and working aerobic capacity as well. In 2006, the first FZ was installed in Maringá, and in 2012 there were 50 FZs strategically located near the Basic Health Units (BHU) in order to facilitate the involvement of the professionals of the Family Health Strategy (FHS) and Expanded Family Health Center (EFHC) [8].

From a practical standpoint, this study is relevant insofar as it provides information on the elements that interfere in the level of physical activity of the elderly that attend the $\mathrm{FZ}$, providing parameters for the development of actions to increase the practice of physical activity among the elderly.

In view of the above, this study aimed at identifying the level of physical activity and its associated factors related to the elderly who usually go to third age fitness centers in Maringá/PR.

\section{Methods}

\section{Subjects}

A total of 970 people aged 60 years and over, selected by means of a convenience sample, and that used the FZ from the municipality of Maringá, state of Paraná, participated in this study. Due to the low prevalence of the elderly who go to some of the FZ, $23 \mathrm{FZs}$ were excluded from data collection. Therefore, out of the total of $57 \mathrm{FZs}$ from the municipality that existed at the time of data collection, $34 \mathrm{FZs}$ were assessed. Elderly of both sexes, users of at least one of the FZ for three months and twice a week, with preserved speech and hearing capacity, were included. The exclusion criteria adopted were the following: elderly who wore walking devices, with neurological and dementia deficits reported by caregivers and/or family members at the time of data collection, in addition to the incapacity of carrying out the research. Older people with possible cognitive deficits were also excluded, evaluated according to the Mini Mental State Examination (MMSE) [9]. 
Instruments

A semi-structured questionnaire was used for featuring the elderly sociodemographic and health characteristics, which consisted of information on sex (male, female), marital status (married or living with a partner, single, divorced, widower), age group 60-69-year-old; 70-79-year-old; 80 years old or more), the monthly income in minimum wage (MW) (1 to $2 \mathrm{MW}, 2.1$ to $3 \mathrm{MW}$; $3 \mathrm{MW}$ ); education (illiterate, incomplete elementary school, complete elementary school, complete high school, higher education); own residence (yes, no); race (white, black, Asian/Indian); retirement (yes, no); self-perception of the health status (excellent, very good/good, bad/regular); comparison of health with a person of the same age (better, equal, worse); medicines used (none, 1 to 2, more than 2); and recommendation to go to the FZ (medical recommendation, recommendation from another health professional, family/friends, no recommendation). In addition, we have investigated the presence of falls and some diseases, such as osteoporosis. This instrument was prepared by the authors themselves.

The MMSE [9] consists of questions grouped into seven categories: temporal orientation, spatial orientation, three-word register, attention and calculation, recall of the three words, and language visual-constructional ability. The exclusion cutoff scores used by the MMSE were the following: 17 for the illiterate; 22 for the elderly with 1-to-4-yeareducation stages; 24 for those with 5-to-8-education stages and 26 for the subjects who had studied for 9 years or more. Such cutoff scores correspond to the average obtained by these authors for each education stage, minus the standard deviation [10]. The elderly classified below the cut-off score specific to their education were excluded.

The physical activity level of the elderly was assessed by applying the short form of the International Physical Activity Questionnaire (IPAQ). It embraces seven open questions and its information allows estimating the time spent per week in different dimensions of physical activity (walking and moderate-to-vigorous physical activities); physical inactivity (sitting position). The physical activity level was classified as irregularly active (the elderly who did physical activity, however, insufficiently to be classified as active subjects because they did not meet the recommendations regarding frequency or duration); active (the elderly who did at least 3 days of vigorous activity for at least 20 minutes, or 5 days or more of moderate activity or walking for at least 30 minutes, or at least 5 days and 150 minutes per week of any type of physical activity); very active (the elderly who did vigorous activities for at least 5 days a week, 30 minutes per session, or at least 3 days a week of vigorous activity, at least 20 minutes per session; more moderate activities or walking for at least 5 days a week and 30 minutes per session). Sedentary behavior was assessed by means of the average sitting time on a weekday, and on a weekend day $[11,12]$.

\section{Procedures}

This is a quantitative observational crosssectional study approved by the research ethics committee from the University Center of Maringá (2.255.102/2017).

Firstly, the Secretary of State for Sport and Recreation was contacted in order to obtain an authorization for data collection at the FZs. Afterwards, the number and locations of the FZs distributed in the municipality (with the exception of the districts) were identified in this same public department. They were divided into the north, south, east and west regions of the city and a random raffle was carried out for those who would participate in the survey.

A team of 10 researchers was previously trained and, after a pilot data collection, they were distributed among the research locations. The researchers approached the elderly in the FZs in different days of the week and at different times. Those who accepted to participate had to sign the Participant Information and Consent Form (PICF). The instruments were applied in the form of an individual interview in order to avoid any misunderstanding or difficulty of reading by the elderly; each interview lasted approximately 20 minutes. Data collection was carried out from June to August 2017.

\section{Data analysis}

Data analysis was carried out by using the SPSS 22.0 Software with a descriptive inferential statistics approach. Frequency and percentage were used as descriptive measures for the categorical variables. Pearson's Chi-squared test (X2) was used to verify the associations among the sociodemographic variables and health conditions with the physical activity level. The Binary Logistic Regression (crude and adjusted analysis) was used to evaluate the association of 
magnitude of the sociodemographic variables and health conditions (independent variables) with the active/very active physical activity level (dependent variable). For modeling the regression analysis, only the variables that had a level of significance equal to or less than 0.20 in the chi-squared test were considered, which were simultaneously inserted in a single block, without withdrawal after the crude analysis. Each exploratory variable that showed a $\mathrm{p}$ value $<0.05$ according to the Wald test was considered to be associated with the study outcome. The model adjustment was verified by using the Hosmer-Lemeshow test.

\section{Results}

Out of the 970 subjects assessed, 728 (75.1\%) were classified as active/very active, whereas 242 (24.9\%) were classified as irregularly active. When analyzing the association between the physical activity level and the sociodemographic variables, a significant association was found only related to the marital status $(\mathrm{P}=0.047)$ and education $(\mathrm{P}=0.001)$, which indicates that being married and having completed higher education is significantly associated with higher physical activity level. (Table 1).

Table 1 - Association between the physical activity level and the sociodemographic variables of the elderly who go to the FZ in Maringá/PR, Brazil $(n=970)$

\begin{tabular}{|c|c|c|c|c|}
\hline \multirow{3}{*}{ VARIABLES } & \multicolumn{2}{|c|}{ Physical Activity Level } & \multirow{3}{*}{$\mathrm{X}^{2}$} & \multirow{3}{*}{$\mathbf{P}$} \\
\hline & Active/Very active $(n=728)$ & Sedentary/Irregularly active $(n=242)$ & & \\
\hline & $f(\%)$ & $f(\%)$ & & \\
\hline \multicolumn{5}{|l|}{ Sex } \\
\hline Male & $323(75.5)$ & $105(24.5)$ & \multirow{2}{*}{0.043} & \multirow{2}{*}{0.835} \\
\hline Female & $404(74.7)$ & $137(25.3)$ & & \\
\hline \multicolumn{5}{|l|}{ Age group } \\
\hline 60-69-year-old & $451(77.1)$ & $134(22.9)$ & \multirow{3}{*}{2.384} & \multirow{3}{*}{0.123} \\
\hline 70-79-year-old & $218(71.5)$ & $87(28.5)$ & & \\
\hline 80 years old or more & $58(73.4)$ & $21(26.6)$ & & \\
\hline \multicolumn{5}{|l|}{ Marital status } \\
\hline Married & 468 (77.7) & 134 (22.3) & \multirow{4}{*}{3.938} & \multirow{4}{*}{$0.047^{*}$} \\
\hline Single & $46(68.7)$ & $21(31.3)$ & & \\
\hline Divorced & $72(67.9)$ & 34 (32.1) & & \\
\hline Widower & $141(72.7)$ & $53(27.3)$ & & \\
\hline \multicolumn{5}{|l|}{ Race } \\
\hline White & $545(74.5)$ & $187(25.5)$ & \multirow{3}{*}{0.782} & \multirow{3}{*}{0.377} \\
\hline Black & $93(75.0)$ & $31(25.0)$ & & \\
\hline Asian/Índian & $85(78.7)$ & $23(21.3)$ & & \\
\hline \multicolumn{5}{|l|}{ Education } \\
\hline Illitarate & $40(65.6)$ & $21(34.4)$ & \multirow{5}{*}{11.010} & \multirow{5}{*}{$0.001^{*}$} \\
\hline Incomplete elementary education & $230(72.6)$ & $87(27.4)$ & & \\
\hline Complete elementary education & $176(73.6)$ & $63(26.4)$ & & \\
\hline Complete high school & $146(76.0)$ & $46(24.0)$ & & \\
\hline Complete higher school & $133(85.3)$ & $23(14.7)$ & & \\
\hline \multicolumn{5}{|l|}{ Retirement } \\
\hline No & $519(74.0)$ & $182(26.0)$ & \multirow{2}{*}{0.692} & \multirow{2}{*}{0.405} \\
\hline Yes & $200(76.9)$ & $60(23.1)$ & & \\
\hline \multicolumn{5}{|l|}{ Monthly income } \\
\hline 1 to $2 \mathrm{MW}$ & 304 (72.6) & 115 (27.4) & \multirow{3}{*}{2.004} & \multirow{3}{*}{0.157} \\
\hline 2 to $3 \mathrm{MW}$ & 191 (77.3) & $56(22.7)$ & & \\
\hline More than $3 \mathrm{MW}$ & $93(77.5)$ & $27(22.5)$ & & \\
\hline
\end{tabular}

Note: * Significant association $-\mathrm{P}<0.05$ : Qui-squared Test for the ratios. 
Different from the sociodemographic variables, the majority of health-related variables were significantly associated $(\mathrm{P}<0.05)$ with the physical activity level (Table 2). There was a significant association between the physical activity level and health perception $(\mathrm{P}=0.037)$, the amount of medicines used $(\mathrm{P}=0.008)$, and history of near-falls in the last semester $(\mathrm{P}=0.038)$. It is worth mentioning that the excellent health perception, the non-use of medicines and no history of near-falls were associated with the physical activity practice.

Table 2 - Association between the physical activity level and the health-related variables of the elderly who go to the FZ in Maringá/PR, Brazil $(\mathrm{n}=970)$

\begin{tabular}{|c|c|c|c|c|}
\hline \multirow{3}{*}{ VARIABLES } & \multicolumn{2}{|c|}{ Physical Activity Level } & \multirow{3}{*}{$\mathrm{X}^{2}$} & \multirow{3}{*}{$\mathbf{P}$} \\
\hline & Active/Very active $(n=728)$ & $\begin{array}{l}\text { Sedentary/Irregularly } \\
\text { active }(n=242)\end{array}$ & & \\
\hline & $f(\%)$ & $f(\%)$ & & \\
\hline \multicolumn{5}{|l|}{ Health self-percetion } \\
\hline Excelent & $199(81.2)$ & $46(18.8)$ & \multirow{3}{*}{4.329} & \multirow{3}{*}{$0.037^{\star}$} \\
\hline Very good/good & $374(72.9)$ & $139(27.1)$ & & \\
\hline Regular/bad & $155(73.1)$ & $57(26.9)$ & & \\
\hline \multicolumn{5}{|l|}{ Medications Used ${ }^{\mathrm{a}}$} \\
\hline None & $213(82.2)$ & $46(17.8)$ & \multirow{3}{*}{7.017} & \multirow{3}{*}{$0.008^{*}$} \\
\hline Up to 2 & $377(72.8)$ & $141(27.2)$ & & \\
\hline More than 3 & $137(72.1)$ & $53(27.9)$ & & \\
\hline \multicolumn{5}{|c|}{ Medical appointment in the last 6 months ${ }^{a}$} \\
\hline Yes & $480(74.1)$ & $168(25.9)$ & \multirow{2}{*}{0.799} & \multirow{2}{*}{0.372} \\
\hline No & $247(76.9)$ & $74(23.1)$ & & \\
\hline \multicolumn{5}{|c|}{ Falls in the last 6 months ${ }^{a}$} \\
\hline Yes & $75(70.1)$ & $32(29.9)$ & \multirow{2}{*}{1.344} & \multirow{2}{*}{0.246} \\
\hline No & $650(75.8)$ & $208(24.2)$ & & \\
\hline \multicolumn{5}{|c|}{ Near falls in the last 6 months ${ }^{a}$} \\
\hline Yes & $129(69.4)$ & $57(30.6)$ & \multirow{2}{*}{4.323} & \multirow{2}{*}{$0.038^{*}$} \\
\hline No & $586(77.0)$ & $175(23.0)$ & & \\
\hline
\end{tabular}

Note: * Significant association $-\mathrm{P}<0,05$ : Chi-squared Test for the ratios; a Variables with absent cases.

The analysis according to the diseases reported by the subjects (Table 3$)$, only diabetes $(\mathrm{P}=0.003)$ and osteoporosis $(\mathrm{P}=0.001)$ were significantly associated with the physical activity level. It is worth mentioning that the absence of diabetes and osteoporosis was associated with physical activity practice.

Table 3 - Association between the physical activity level and the diseases reported by the elderly who go to the FZ in Maringá/PR, Brazil $(n=970)$

\begin{tabular}{|c|c|c|c|c|}
\hline \multirow[b]{2}{*}{ VARIABLES } & \multicolumn{2}{|c|}{ Physical Activity Level } & \multirow[b]{2}{*}{$X^{2}$} & \multirow[b]{2}{*}{$\mathbf{P}$} \\
\hline & $\begin{array}{l}\text { Active/Very active } \\
(\mathrm{n}=728)\end{array}$ & Sedentary/Irregularly active $(n=242)$ & & \\
\hline & $f(\%)$ & $f(\%)$ & & \\
\hline \multicolumn{5}{|c|}{ Heart Disease } \\
\hline Yes & $92(71.3)$ & $37(28.7)$ & \multirow{2}{*}{0.876} & \multirow{2}{*}{0.349} \\
\hline No & $635(75.6)$ & $205(24.4)$ & & \\
\hline \multicolumn{5}{|c|}{ Hypertension ${ }^{\mathrm{a}}$} \\
\hline Yes & $293(72.3)$ & $112(27.7)$ & \multirow{2}{*}{2.331} & \multirow{2}{*}{0.127} \\
\hline No & $432(76.9)$ & $130(23.1)$ & & \\
\hline \multicolumn{5}{|l|}{ Stroke $^{a}$} \\
\hline Yes & $31(81.6)$ & $7(18.4)$ & \multirow{2}{*}{0.584} & \multirow{2}{*}{0.445} \\
\hline No & $695(74.7)$ & $235(25.3)$ & & \\
\hline \multicolumn{5}{|l|}{ Diabetes $^{\mathrm{a}}$} \\
\hline Yes & $142(67.0)$ & $70(33.0)$ & \multirow{2}{*}{8.904} & \multirow{2}{*}{$0.003^{*}$} \\
\hline No & $583(77.3)$ & $171(22.7)$ & & \\
\hline
\end{tabular}




\begin{tabular}{|c|c|c|c|c|}
\hline \multirow{3}{*}{ VARIABLES } & \multicolumn{2}{|c|}{ Physical Activity Level } & \multirow{3}{*}{$X^{2}$} & \multirow{3}{*}{$\mathbf{P}$} \\
\hline & $\begin{array}{l}\text { Active/Very active } \\
(\mathrm{n}=728)\end{array}$ & Sedentary/Irregularly active $(n=242)$ & & \\
\hline & $f(\%)$ & $f(\%)$ & & \\
\hline \multicolumn{5}{|l|}{ Cancer $^{\mathrm{a}}$} \\
\hline Yes & $17(68.0)$ & $8(32.0)$ & \multirow{2}{*}{0.342} & \multirow{2}{*}{0.559} \\
\hline No & 709 (75.2) & $234(24.8)$ & & \\
\hline \multicolumn{5}{|c|}{ 0stearthritis ${ }^{\mathrm{a}}$} \\
\hline Yes & $106(70.7)$ & $44(29.3)$ & \multirow{2}{*}{1.846} & \multirow{2}{*}{0.174} \\
\hline No & $620(75.9)$ & $197(24.1)$ & & \\
\hline \multicolumn{5}{|c|}{ Respiratory disease $^{\mathrm{a}}$} \\
\hline Yes & $43(68.3)$ & $20(31.7)$ & \multirow{2}{*}{1.273} & \multirow{2}{*}{0.259} \\
\hline No & $683(75.5)$ & $222(24.5)$ & & \\
\hline \multicolumn{5}{|l|}{ Depression $^{\mathrm{a}}$} \\
\hline Yes & $64(67.4)$ & $31(32.6)$ & \multirow{2}{*}{2.836} & \multirow[b]{2}{*}{0.092} \\
\hline No & $662(75.8)$ & $211(24.2)$ & & \\
\hline \multicolumn{5}{|c|}{ Osteoporosis $^{\mathrm{a}}$} \\
\hline Yes & $88(62.0)$ & $54(38.0)$ & \multirow{2}{*}{14.271} & \multirow{2}{*}{$0.001^{*}$} \\
\hline No & $635(77.3)$ & $187(22.7)$ & & \\
\hline
\end{tabular}

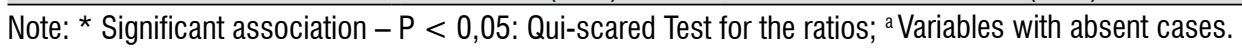

Table 4 shows the sociodemographic and health factors associated with the active/very active physical activity levels of those who practice exercises. Considering the crude analysis, there was a significant association $(\mathrm{P}<0.05)$ of the active/ very active physical activity level with marital status, health self-perception, amount of medications, nearfalls history, diabetes and osteoporosis.

Table 4 - The crude odds ratio, and the adjusted ones for the active/very active level of physical activity and the factors associated with the elderly who go to the FZ in Maringá/PR, Brazil $(n=970)$

\begin{tabular}{|c|c|c|c|c|}
\hline VARIABLES & $\begin{array}{l}\text { Crude OR } \\
\text { (Cl 95(\%) }\end{array}$ & $\mathbf{P}$ & Adjusted OR (Cl 95(\%) & $\mathbf{P}$ \\
\hline \multicolumn{5}{|l|}{ Age group } \\
\hline 60-69-year-old & 1.00 & & 1.00 & - \\
\hline 70-79-year-old & $0.745[0.544-1.020]$ & 0.066 & $1.107[0.757-1.618]$ & 0.601 \\
\hline 80 years old or more & $0.821[0.481-1.401]$ & 0.469 & $1.052[0.564-1.964]$ & 0.872 \\
\hline \multicolumn{5}{|l|}{ Marital status } \\
\hline Married & 1.00 & - & 1.00 & - \\
\hline Single & $0.627[0.362-1.088]$ & 0.097 & $0.497[0.266-0.931]$ & $0.029 *$ \\
\hline Divorced & $0.606[0.386-0.952]$ & $0.030^{*}$ & $0.572[0.336-0.974]$ & $0.040^{*}$ \\
\hline Widower & $0.762[0.526-1.102]$ & 0.149 & $0.832[0.543-1.276]$ & 0.400 \\
\hline \multicolumn{5}{|l|}{ Monthly Income ${ }^{a}$} \\
\hline 1 to $2 \mathrm{MW}$ & 1.00 & - & 1.00 & - \\
\hline 2 to $3 \mathrm{MW}$ & $1.290[0.894-1.862]$ & 0.174 & $1.278[0.864-1.890]$ & 0.219 \\
\hline More than $3 \mathrm{MW}$ & $1.303[0.807-2.104]$ & 0.279 & $1.140[0.691-1.880]$ & 0.609 \\
\hline \multicolumn{5}{|l|}{ Health selfperception } \\
\hline Excellent & 1.00 & - & 1.00 & - \\
\hline Very good/good & $0.622[0.427-0.905]$ & $0.013^{*}$ & $0.795[0.514-1.229]$ & 0.302 \\
\hline Regular/bad & $0.629[0.404-0.978]$ & $0.039 *$ & $0.874[0.508-1.503]$ & 0.625 \\
\hline \multicolumn{5}{|l|}{ Medicines } \\
\hline None & 1.00 & - & 1.00 & - \\
\hline Up to 2 & $0.577[0.398-0.838]$ & $0.004^{*}$ & $0.774[0.490-1.223]$ & 0.272 \\
\hline More than 3 & $0.558[0.356-0.875]$ & $0.011^{*}$ & $0.871[0.481-1.579]$ & 0.650 \\
\hline
\end{tabular}




\begin{tabular}{|c|c|c|c|c|}
\hline \multicolumn{5}{|l|}{ (Conclusion) } \\
\hline VARIABLES & $\begin{array}{l}\text { Crude OR } \\
\text { (Cl 95(\%) }\end{array}$ & $\mathbf{P}$ & Adjusted OR (Cl 95(\%) & $\mathbf{P}$ \\
\hline \multicolumn{5}{|l|}{ Near-falls } \\
\hline Yes & 1.00 & - & 1.00 & - \\
\hline No & 1.480 [1.038-2.109] & $0.030 *$ & 1.671 [1.009-2.613] & $0.047^{\star}$ \\
\hline \multicolumn{5}{|l|}{ Hypertension } \\
\hline Yes & 1.00 & - & 1.00 & - \\
\hline No & 1.270 [0.948-1.703] & 0.110 & 1.160 [0.796-1.689] & 0.440 \\
\hline \multicolumn{5}{|l|}{ Diabetes } \\
\hline Yes & 1.00 & - & 1.00 & - \\
\hline No & 1.681 [1.204-2.345] & $0.002^{*}$ & $1.030[0.676-1.569]$ & 0.892 \\
\hline \multicolumn{5}{|l|}{ Osteoarthritis } \\
\hline Yes & 1.00 & - & 1.00 & - \\
\hline No & $1.306[0.888-1.922]$ & 0.175 & 0.837 [0.509-1.375] & 0.482 \\
\hline \multicolumn{5}{|l|}{ Depression $^{\mathrm{a}}$} \\
\hline Yes & 1.00 & - & 1.00 & - \\
\hline No & 1.520 [0.963-2.398] & 0.072 & $1.426[0.831-2.449]$ & 0.198 \\
\hline \multicolumn{5}{|l|}{ Osteoporosis ${ }^{a}$} \\
\hline Yes & 1.00 & - & 1.00 & - \\
\hline No & 2.084 [1.431-3.035] & $0.001^{*}$ & 1.891 [1.008-2.915] & $0.045^{*}$ \\
\hline
\end{tabular}

Note: * Significant association - P < 0.05: Binary Logistic Regression; Adjusted OR: for all the model variables; OR: odds ratio; Cl: confidence interval.

When the analysis was adjusted by all the model variables (Table 4), only the marital status, near-fall history and osteoporosis were associated with the active/very active physical activity level. It is worth mentioning that the subjects who had no history of near-falls in the last six months and who did not have osteoporosis were $1.671(95 \% \mathrm{CI}=1.009-2.613)$ and $1.891(95 \% \mathrm{CI}=1.008-2.915)$ times more likely to be active/very active when compared to the elderly who had near-falls in the last semester and who had osteoporosis. The marital status (married) was seen as a protection factor, that is, the married women are $50 \%$ more likely to be physically active than the single ones, and $43 \%$ more likely than the divorced individuals.

\section{Discussion}

In this study, it was found that the elderly who resort to FZ are mostly physically active, indicating that these physical activity leisure spaces are important so that the elderly can be on the move. The literature shows that the benefits of physical activity and longevity are consensual among the health professionals who emphasize the importance of stimulating physical activity practice in public health actions. However, few studies have been carried out with individuals who go to FZ, which makes it difficult to compare the results of this research.

Most of the elderly herein assessed were classified by the IPAQ as active/very active subjects, and $24.9 \%$ as sedentary/irregularly active subjects. There was a lower rate of physical inactivity than that observed in a population of older people in the cities of Rio Grande do Sul and Santa Catarina (47.3\%), and in some cities of the Northeast region of the country (67.5\%) [13]. Considering the worldwide prevalence of physical inactivity (21.4\%), estimated by Dumith et al. [14] the frequency of such behavior in the population of the present study must be considered as adequate. National initiatives, such as the third age fitness centers for the elderly are useful for reducing the sedentary lifestyle in the population.

There was a statistically significant association with marital status and education. There is no consensus in the literature between the physical activity level and marital status. Some studies have found greater inactivity for divorced individuals and widowers [15], and others in individuals living with their partners [16]. Education is directly related to financial conditions. Cassou [17] and Pitanga and Lessa [15] reported that people from low-income and education segments would have less access to the equipment, adequate safe public locations for physical activity practice, or even to private high-paid gyms. Moreover, these subjects 
do not have information either on physical activity or health, nor guidance from health professionals, in addition to their life conditions that prevent the incorporation of healthy practices. According to Pan et al. [18], individuals with a higher education level, as well as a higher income, have more opportunities, besides living in a social environment in which the practice is recognized by their counterparts as being favorable to health, which may facilitate accession. According to the authors, these groups tend to show better health conditions, better social support, and assimilate more easily the recommendations and benefits of regular physical activity [19].

The factors related to good health status (good health perception, absence of diabetes and osteoporosis, non-use or less medication use, no history of falls) are associated with greater physical activity practice, as shown in the present study. According to Lima-Costa, Firmo and Uchôa [20] and Pagotto, Bachion and Silveira [21] health selfperception is considered an important indicator of the elderly health status, since it incorporates physical, cognitive and emotional aspects, as well as the aspects related to well-being and satisfaction with life itself. In addition, such self-protection has been widely used in population studies with older people because it is consistently associated with morbimortality and functional decline in this age group [22-24].

The greater use of medicines by the elderly is related to a high frequency of chronic diseases and pain. Inactive long-lived older women have reported that pain in the lower and upper limbs, lumbar and/ or cervical spine, and the body in general, makes it difficult for them to practice regular physical activity [25], and accomplish habitual tasks. Moreover, considering daily life, the low physical activity level of people must lead to functional mobility loss, strength and muscular endurance, which may cause falls. Diseases and disability reduce the physical activity level which, in turn, predisposes the elderly to a greater risk of diseases and disability [26]. On the other hand, the regular physical activity practice shall positively interfere in the improvement of pain and use of medicines. There is strong epidemiological evidence that an active lifestyle is a fundamental factor in the prevention, treatment and control of chronic diseases [27].

Other studies were also carried out with the elderly in the gyms of the Third Age in the state of Paraná [28-29]. One of them in Maringá - PR, analyzed the behavior of blood pressure and heart rate, showing that these sites are important for maintaining cardiovascular health [28]. In addition, another study in Matelândia - PR identified the factors associated with the physical activity of the elderly and verified a large number of active / very active elderly, and this was associated with lower age, less use of medication, use of medication and indication of physical activity [29].

The cross-sectional model is a limitation of this study because it restricts the assessment of the cause and the variables effect, and, thus, the interpretation of the results must be made with caution. The use of information referred to physical activity by means of a questionnaire is also a limitation, since it confers a greater margin of error when compared to the direct measures of the physical activity level that use measuring equipment. However, the advantages of using self-referenced questionnaires refer to the low cost and speed to obtain the data [30].

\section{Conclusion}

It was concluded that sociodemographic variables and health conditions are associated to the physical activity level. Specifically, being married, having completed higher education, perceiving with excellent health, the non-use of medicines, no history of nearfalls, the absence of diabetes and osteoporosis were associated with the higher physical activity level. Further, elderly who reported the absence of a history of near falls and osteoporosis have more chance to be physically active. From a practical point of view, creating leisure spaces where the elderly can practice physical activities, such as the FZ, is important for their physical maintenance, in addition to preventing falls and diseases, such as osteoporosis, since a good health condition favor the permanence of the elderly in physical activities.

\section{References}

1. World Health Organization. Envelhecimento ativo: uma política de saúde. Brasília, DF: Organização PanAmericana da Saúde; 2005.

2. Ferrari CKB. Implementation of public health policies for healthy lifestyles promotion: what Brazil should tell us?. Health Promot Perspect. 2018;8(3):242-8. 
3. Palácios AROP, Salineiro APSB, Nardi ACF, Rosaneli CF. A concepção do programa Maringá Saudável, suas ações e resultados. Divulg Saude Debate. 2009;44(1):34-40.

4. Towne SD Jr, Li Y, Lee S, Smith ML, Han G, Quinn C, et al. Physical activity and associated medical cost savings among at-risk older adults participating a community-based health \& wellness program. PLoS One. 2018;13(6):e0198239.

5. Benedetti TRB, Borges LJ, Petroski EL, Gonçalves LHT. Physical activity and mental health status among elderly people. Rev Saude Publica. 2008;42(2):302-7.

6. Fernandez-Alonso L, Muñoz-García D, La Touche R. The level of physical activity affects the health of older adults despite being active. J Exerc Rehabil, 2016;12(3):194-201.

7. Instituto Brasileiro de Geografia e Estatística. Censo demográfico 2010: características da população e dos domićlios. Rio de Janeiro: IBGE; 2010.

8. Nardi ACF. A utilização das academias da terceira idade na promoção da saúde em Maringá-PR [thesis]. Brasília, DF: Universidade de Brasília; 2013.

9. Folstein MF, Folstein SE, McHugh PR. Mini mental State: a practical method for grading the cognitive state of patients for clinician. J Psychiatr Res. 1975;12(1):189-98.

10. Brucki SMD, Nitrini R, Caramelli P, Bertolucci PHF, Okamoto IH. Sugestões para o uso do mini-exame do estado mental no Brasil. Arq Neuro-Psiquiatr. 2003;61(3B):777-81.

11. Craig CL, Marshall AL, Sjöström M, Bauman AE, Booth ML, Ainsworth BE, et al. International physical activity questionnaire: 12 -country reliability and validity. Med Sci Sports Exerc. 2003;35(8):1381-95.

12. Matsudo S, Araújo T, Matsudo V, Andrade D, Andrade E, Oliveira LC, et al. Questionário internacional de atividade física (IPAQ): estudo de validade e reprodutibilidade no Brasil. Rev Bras Ativ Fis Saude. 2001;6(2):5-18.
13. Siqueira FV, Facchini LA, Piccini RX, Tomasi E, Thumé E, Silveira DS, et al. Atividade física em adultos e idosos residentes em áreas de abrangência de unidades básicas de saúde de municípios das regiões Sul e Nordeste do Brasil. Cad Saude Publica. 2008;24(1):39-54.

14. Dumith SC, Hallal PC, Reis RS, Kohl HW III. Worldwide prevalence of physical inactivity and its association with human development index in 76 countries. Prev Med. 2011;53(1-2):24-8.

15. Pitanga FJG, Lessa I. Prevalência e fatores associados ao sedentarismo no lazer em adultos. Cad Saude Publica. 2005;21(3):870-7.

16. Dias-da-Costa JS, Hallal PC, Wells JCK, Daltoé T, Fuchs SC, Menezes AMB, et al. Epidemiology of leisure time physical activity: a population-based study in southern Brazil. Cad Saude Publica. 2005;21(1):275-82.

17. Cassou ACN, Fermino RC, Santos MS, RodriguezAñez CR, Reis RS. Barreiras para a atividade física em idosos: uma análise por grupos focais. Rev Educ Fis UEM. 2008;19(3):353-60.

18. Pan SY, Cameron C, DesMeules M, Morrison H, Craig $\mathrm{CL}$, Jiang $\mathrm{XH}$. Individual, social, environmental, and physical environmental correlates with physical activity among Canadians: a cross-sectional study. BMC Public Health. 2009;9:1-12.

19. Teunissen E, Sherally J, van den Muijsenbergh M, Dowrick C, van Weel-Baumgarten E, van Weel C. Mental health problems of undocumented migrants (UMs) in the Netherlands: a qualitative exploration of help-seeking behaviour and experiences with primary care. BMJ open. 2014;4(11),:e005738.

20. Lima-Costa MF, Firmo JOA, Uchôa E. A estrutura da auto-avaliação da saúde entre idosos: projeto Bambuí. Rev Saude Publica. 2004;38(6):827-34.

21. Pagotto V, Bachion MM, Silveira EA. Autoavaliação da saúde por idosos brasileiros: revisão sistemática da literatura. Rev Panam Salud Publica. 2013;33(4):302-10. 
22. Borim FSA, Barros MBA, Neri AL. Autoavaliação da saúde em idosos: pesquisa de base populacional no Município de Campinas, São Paulo, Brasil. Cad Saude Publica. 2012;28(4):769-80.

23. Schneider G, Driesch G, Kruse A, Wachter M, Nehen HG, Heuft G. What influences self-perception of health in the elderly? The role of objective health condition, subjective well-being and sense of coherence. Arch Gerontol Geriatr. 2004;39(3), 227-37.

24. Levy BR, Myers LM. Preventive health behaviors influenced by self-perceptions of aging. Prev Med. 2004;39(3):625-9.

25. Krug RR, Lopes MA, Mazo GZ, Marchesan M. A dor dificulta a prática deatividade física regular na percepção de idosas longevas. Rev Dor. 2013;14(3):192-5.

26. Coelho CF, Burini RC. Atividade física para prevenção e tratamento das doenças crônicas não transmissíveis e da incapacidade funcional. Rev Nutr. 2009;22(6):937-46.

27. Matsudo SM, Matsudo VK. Physical activity and ageing in developing countries. Perspectives. 2000;2:65-84.
28. Leonel SO Jr, Antunes MD, Ovando RGM, Araújo APS, Bortolozzi F, Bernuci MP, et al. Equipment in senior gyms: influence on the behavior of blood pressure and heart rate of elderlies. Geriatr Gerontol Aging. 2017;11(4):158-64.

29. Oliveira DV, Brito RL, Antunes MD, Nascimento JRA Jr, Moreira CR, Oliveira DC, et al. Practice of physical activity by elderly frequenters of basic health units. Geriatr Gerontol Aging. 2017;11(3):116-23.

30. Hallal PC, Dumith SC, Bastos JP, Reichert FF, Siqueira FV, Azevedo MR. Evolução da pesquisa epidemiológica em atividade física no Brasil: revisão sistemática. Rev Saude Publica. 2007;41(3):453-60.

Received in 08/09/2018

Recebido em 09/08/2018

Recibido en 09/08/2018

Approved in 07/22/2019 Aprovado em 22/07/2019 Aprobado en 22/07/2019 